\title{
POSSIBILITIES OF USING PRICE ANALYSIS IN DECISION MAKING ON THE USE OF HARVESTER TECHNOLOGY IN FORESTRY
}

\author{
L. Bartoš, P. Máchal, A. Skoupý
}

Received: May 14, 2009

\begin{abstract}
BARTOŠ, L., MÁCHAL, P., SKOUPÝ, A.: Possibilities of using price analysis in decision making on the use of harvester technology in forestry. Acta univ. agric. et silvic. Mendel. Brun., 2009, LVII, No. 4, pp. 31-36

The concept of harvester technology is understood as a fully mechanized harvesting technology for the purpose of timber logging, which means timber handling, extraction and forwarding or skidding. This complete harvesting technology consists of two different assignments of accommodated, specialized logging machines - harvester and forwarder.

This timber harvesting technology currently represents a state-of-the-art technology in logging and transport of timber in forestry. This is because the efficiency of the "harvester and forwarder" combination is several times higher than that of the commonly used technology of "power saw and tractor" (Lukáč, T., 2005). Other important elements that prevail with harvester technologies are a not negligible and high degree of labour hygiene as well as a significant decrease of environmental load influencing the environment.

This paper analyzes prices of works related to timber harvesting and skidding in the selected forest stands of concerned workplaces.
\end{abstract}

harvester technologies, harvester, forwarder, price of service

One of factors decisive for the utilization of harvester technologies in timber logging are economic conditions; together with natural and technical conditions these essentially influence the utilization of multi-operational machinery (Kupčák, V., 2003).

The application of logging and hauling machines at the fulfilment of economic assignments in both private and municipal, military and state-owned forests is currently an absolute necessity.

Main requirement of the forest owner in the application of any technology of timber logging and skidding is compliance of the technology with the existing environmental conditions at a simultaneous respecting of the production and social functions of the forest and relevant economic aspects (Ulrich, R. et al., 2006). It may certainly be assumed that technologies using manual power chainsaws and choker skidding will be retained. On the other hand, one needs to be aware of extensive advantages offered by the technology of multi-operational machines, not only the harvester technologies themselves but their combinations with for example forest cable- ways (the so called mountain processors) or even with the manual power chainsaws, allowing for replacement of wood mass choker skidding by haulage with forwarders (Šajánek, Vl., 2007). It should be pointed out that these integrated logging and hauling technologies are highly demanding for a skilled preparation of both the work and the workplace, the technological process elaborated in detail, and a professional managerial work throughout the production process. The use of a new logging machinery that favourably influences the prices of short lengths produced through high productivity is supported by the increasing wages of forest workers, the almost stagnant and relatively low price of wood in the market, the limited financial means of business entities, and the competition within the wood market. Despite the conservative approach to the usage of harvesters and forwarders at some places, especially in the improvement felling, the machines exhibit a relatively marked increase in numbers, particularly at workplaces of Lesy České republiky (Forests of the Czech Republic). 
Integrated logging and hauling technologies are justified, and with using suitable logging machines of adequate output and proper technologies, in adequate environment (ground bearing capacity, slope gradient, obstacles...), with trained, motivated and competent operators and a high degree of work organization control, including the preparation of forest stand for the machinery, they are necessary for the fulfilment of logging and hauling assignments in forestry practice.

This paper is focused on the issue of using possibilities to put on integrated logging and hauling technologies with selected companies, namely: Vojenské lesy a statky ČR, s. p., Division Lipník nad Bečvou (Military Forests and Farms of the CR, state enterprise, ŠP Valšovice (Training Forest District Valšovice); Městské lesy a zeleň Valašské Meziříčí (Municipal Forests and Greenery Valašské Meziřící). The goal of the paper is to contribute to the possibility of using harvester technology by means of price analysis to facilitate the decision making on the use of the technology, and to propose an adoption of these technologies in the territory of the selected workplaces.

\section{MATERIAL AND METHODS}

This paper makes use of factor description methods and the price analysis for works related to timber logging and skidding. It also provides a comparison of prices for timber logging and skidding services with the technologies used on earmarked forest stands of the concerned workplaces, and a comparison of prices of works between the "power saw and tractor" logging and hauling technology and the harvester technology at selected workplaces. The prices for works were taken from contracts between suppliers and customers. The calculation of labour input for the "power saw and tractor" technology uses performance standards valid for the concerned entity. On the grounds of the analysis performed it was possible to conclude, which of the technologies was more price-demanding for the work submitter (customer).

All the ascertained data were put into a calculation formula containing the representation of suitable site classes, representation of coniferous and deciduous tree species, and the amount of wood mass in site classes with the potential for harvester work.

\section{RESULTS}

The performed analysis was to clarify, which timber harvesting technology is cheaper, or possibly more advantageous: whether it was classical technology, i.e. timber logging by manual power chainsaw and skidding from the "stump" locality $(\mathrm{P})$ to the "roadside" locality (OM) by the tractor (UKT, SLKT and/or a forwarder), or harvester technology, in which the technological unit consists of harvester and forwarder, and as a whole provides for timber logging and skidding from $\mathrm{P}$ locality to OM locality.
To make a relatively objective comparison of both timber harvesting variants at the selected places of work, the evaluation makes use of prices for works. Prices for works done are firmly agreed, with the price determined for $\mathrm{m}^{3}$ of timber harvested and skid from the P locality to the OM locality. In the harvester technology, i.e. in the harvester unit, the price for timber logging and skidding is determined together. In the technology of timber felling by manual power chainsaw and timber skidding that may be carried out by various means of mechanization independent of logging, the prices for services are determined independently for individual operations, and these prices are summed up for the calculation of total price per $1 \mathrm{~m}^{3}$. It is assumed that this work is carried out by a "self-employed person" (licensed). Under these conditions it is then possible to compare the two technologies by calculation, and to establish with a high probability, which of them is economically more advantageous for the concerned entity.

The approach to data processing for the price calculations consisted in the selection of forest stands, in which comparisons would be made for each concerned entity. In the case of ŠP Valšovice and MěLZ Valašské Meziříčí, all cuts implemented by harvester within the period studied were selected for the evaluation. In VLS, s.p., Division Lipník nad Bečvou, a random choice was made of 85 forest stands, in which timber logging was performed by a harvester. The source data were parameters indicated by the harvester:

- Mean stem volume of the felled tree;

- Mean stem volume of the forwarded (skid) tree;

- Forwarding (skidding) distance;

- Salvage timber (biomass affected by bark beetle, windthrows).

Other data, such as branchiness of trees, processing of small-wood biomass etc. that were necessary to calculate labour input, i.e. standard hours for wudcutter work, were ascertained by site inspection. The calculated values were recorded in a synoptic table.

A part of the analysis of the utilization of harvester technologies with VLS, s.p., Lipník n. B. division was also the establishment of the assumed attainment of ascertained minimum felling volumes possible by using these technologies. Volumes of felling carried out by harvester technology within the period in view are relatively well balanced with only a minimum tendency to rise. In case that the application of the technology does not show a more progressive increase within a short time, the felling volumes can be hardly achieved and if so, then in a time horizon of more than ten years. In Diagram 1, the limit of maximum possible felling volumes is shown as the red line, and the green line represents the minimum felling volumes suitable for harvester technologies. The black line shows the current developmental trend in the use of harvester technologies. 


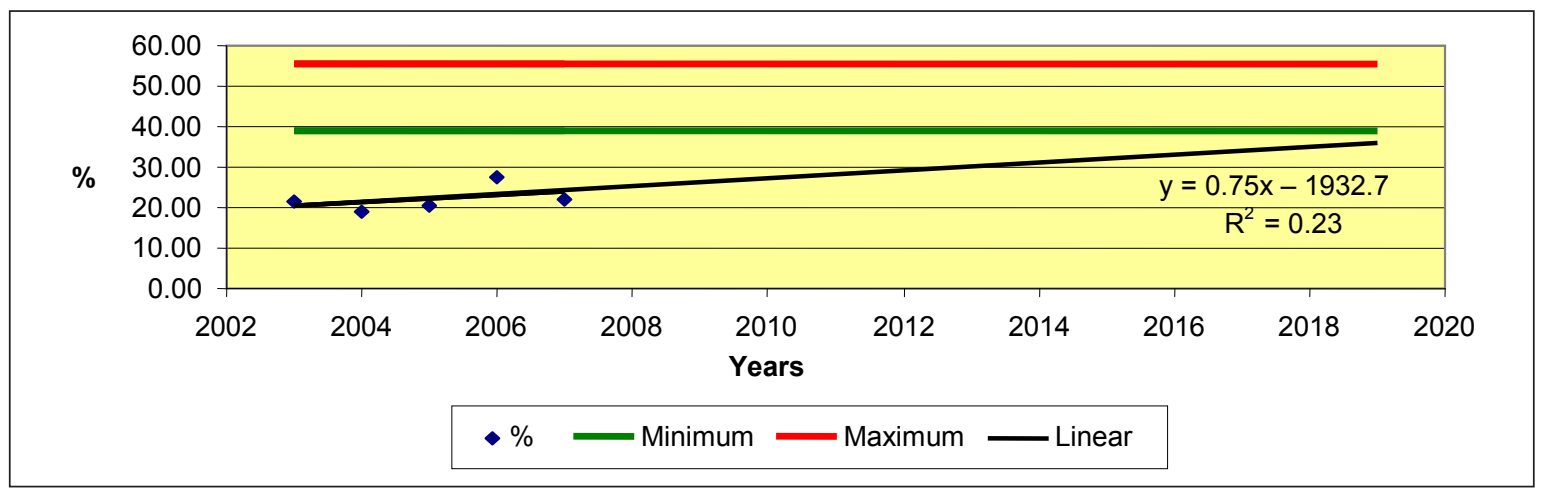

Source: Authors

1: The expected development in the application of harvester technology usage with VLS, s.p., Division Lipnik n. B.

\section{DISCUSSION}

The main requirement of the forest owner in using forest machinery for timber cutting and skidding is to ensure its conformity with environmental conditions at a simultaneous respect to production and social functions of the forest and relevant economic aspects.

It may be safely assumed that technologies utilizing manual power chainsaw and choker skidding will be maintained. On the other hand, it is necessary to realize how great are the possibilities offered by the multi-operational machinery technology, not only as independent harvester technologies but also e.g. in combination with forest cableways (the so-called mountain processors), or even with manual power chainsaws, when the choker skidding of wood mass can be replaced by its haulage with the use of forwarders. It is necessary to emphasize that these integrated logging and hauling technologies impose high demands on the skilled preparation of works and site, the technological process elaborated to details, and professional managerial work throughout the production process. The employment of new logging machines that favourably influences the prices of produced short lengths through high productivity is supported by the increasing wages of forest workers, by the almost stagnant and relatively low price of wood on the market, by limited financial resources of business entities, and by the competition on the timber market. Despite the conservative approach to the use of harvesters and forwarders, especially in improvement felling, which still persists at some places, the number of machines shows a relatively marked increase namely at workplaces of Lesy České republiky (Forests of the Czech Republic).

After having processed all source data and a consequent evaluation, we can conclude as follows:

As compared with the "classical technology", the use of harvester technology at VLS, s. p., Division Lipník nad Bečvou was on average cheaper by $128 \mathrm{CZK}$ per $1 \mathrm{~m}^{3}$. In case that at least a minimum possible percentage of harvester felling operations, i.e. $38.75 \%$ were used in 2007 , which would have ac- counted for roughly $100,200 \mathrm{~m}^{3}$ out of the total annual felling volume of $258,515 \mathrm{~m}^{3}$, it would have been by $42,842 \mathrm{~m}^{3}$ more than in reality (only $22.19 \%$, which was $\left.57,358 \mathrm{~m}^{3}\right)$. A final result would have been savings in prices for timber logging and skidding services amounting to $\mathbf{5 , 4 8 3 , 7 7 6} \mathbf{C Z K}$. Should we have adhered in evaluating the planned annual felling volumes which amount to $163,789 \mathrm{~m}^{3}$, and increased the utilization of harvester technology from the average $22 \%$ to the recommended possible minimum, i.e. $38.76 \%$, which in terms of $\mathrm{m}^{3}$ represents an increase from ca $36,000 \mathrm{~m}^{3}$ to $63,877 \mathrm{~m}^{3}$, it would have been possible to achieve a difference amounting to $27,877 \mathrm{~m}^{3}$ in favour of harvester technology. If we express the value as a difference of price for services in CZK $\left(128 \mathrm{CZK} / \mathrm{m}^{3}\right)$, the resulting value would be 3,568,256 CZK. This amount represents annual saving of money in the production process of timber logging and skidding. In relation to these calculations, it is recommended to increase the number of harvester machines by a minimum of two medium-sized harvester units.

The evaluation of service price differences between the harvester technology and the "power saw and tractor" technology at ŠP Valšovice gave the following results: In both studied periods, the harvester technology was more expensive. In felling operations in the autumn of 2007, the difference amounted to $27 \mathrm{CZK}$ per $\mathrm{m}^{3}(8 \%)$, and in the first quarter of 2008 it was $37 \mathrm{CZK} / \mathrm{m}^{3}$ (10\%). Similarly, in MěLZ Val. Meziř́ící, the evaluation showed the harvester technology to be more expensive than the "power saw + tractor" technology, namely by $40 \mathrm{CZK} / \mathrm{m}^{3}$ (15\%). Although the technology was more expensive, its final effect brought to the concerned entity earnings from timber sales higher by about 500,000 CZK. The reason for such encashment was that the timber harvested in the first two months of 2008 was sold immediately for prices agreed for that quarter of the year. The following quarter, however, recorded a very conspicuous drop of timber prices. It was exactly the speed of processing the felled and skid timber that brought the above effect. 


\section{CONCLUSION}

One of factors decisive for the utilization of harvester technologies for timber logging are economic conditions; together with natural and technical conditions these essentially influence the use of multioperational machinery.

Currently the usage of logging and hauling machinery in the fulfilment of economic assignments in private and municipal, military and state-owned forests is an absolute necessity.
The results of the performed analysis show that all entities in view undervalued the possibilities of timber processing by harvester technologies. To a certain degree this conclusion may be applied to all forest owners. It can be assumed that with a responsible and expert analysis of necessary data about the concerned workplace and with a subsequent choice of an optimum technological procedure it is possible to achieve a significant increase in the percentage of using modern harvester technologies in timber logging and skidding.

\section{SUMMARY}

The main requirement of the forest owner in using forest machinery for timber cutting and skidding is to ensure its conformity with environmental conditions at a simultaneous respect to production and social functions of the forest and relevant economic aspects. It may be safely assumed that technologies utilizing manual power chainsaw and choker skidding will be maintained. On the other hand, it is necessary to realize how great are the possibilities offered by the multi-operational machinery technology, not only as independent harvester technologies but also e.g. in combination with forest cableways (the so-called mountain processors), or even with manual power chainsaws, when the choker skidding of wood mass can be replaced by its haulage with the use of forwarders. These integrated logging and hauling technologies impose high demands on the skilled preparation of works and site, the technological process elaborated to details, and professional managerial work throughout the production process. The employment of new logging machines that favourably influences the prices of produced short lengths through high productivity is supported by the increasing wages of forest workers, by the almost stagnant and relatively low price of wood on the market, by limited financial resources of business entities, and by the competition on the timber market. Despite the conservative approach to the use of harvesters and forwarders, especially in improvement felling, which still persists at some places, the number of machines shows a relatively marked increase namely at workplaces of Lesy České republiky (Forests of the Czech Republic).

The results of the performed analysis indicate that all entities included in the study undervalued possibilities of timber felling by harvester technologies, although their economic advantages cannot be denied.

\section{SOUHRN}

\section{Možnosti využití analýzy cen při rozhodování o nasazení harvestorové technologie} Hlavním požadavkem vlastníka lesa při použití techniky k těžbě a soustřed'ování dříví je zajištění jejího souladu s ekologickými podmínkami, při současném respektování produkčních a společenských funkcí lesa a příslušných ekonomických aspektů. V současné době lze s jistotou předpokládat, že zůstanou i nadále zachovány technologie s využitím ruční motorové řetězové pily a úvazkového soustřed'ování. Na druhé straně je ale třeba si uvědomit, jak velké možnosti nabízí technologie víceoperačních strojů, a to nejen jako samostatné harvestorové technologie, ale např̀. i v kombinaci s lesními lanovkami /tzv. horské procesory/ nebo i ruční motorové řetězové pily, kdy je možné nahradit úvazkové soustřed'ování dřevní hmoty jejím vyvážením s využitím forwarderů. Tyto integrované těžebně-dopravní technologie kladou vysoké nároky na kvalifikovanou přípravu práce i pracoviště, podrobně rozpracovaný technologický postup a profesionální manažerskou práci po celou dobu výrobního procesu. Nasazení nové těžební techniky, která ovlivňuje vysokou produktivitou příznivě ceny vyrobených dřevních sortimentů, podporují stoupající mzdy lesních dělníků, téměř stagnující a relativně nízká cena dřeva na trhu, omezené finanční prostředky podnikajících subjektů a konkurence na trhu se dřevem.

Je třeba zdůraznit, že tyto integrované těžebně-dopravní technologie kladou vysoké nároky na kvalifikovanou přípravu práce i pracoviště, podrobně rozpracovaný technologický postup a profesionální manažerskou práci po celou dobu výrobního procesu. Přes ještě někde stále přetrvávající konzervativní přístup k používání harvestorů a forwarderů, obzvláště ve výchovných těžbách, dochází k poměrně výraznému nárůstu počtu těchto strojů zejména na pracovištích Lesů České republiky. Z výsledků provedené analýzy vyplývá, že u všech sledovaných subjektů dochází k podhodnocení možností zpracování těžeb harvesterovými technologiemi, jejichž ekonomická výhodnost je neodiskutovatelná.

harvestorové technologie, harvestor, forwarder, cena služeb 


\section{REFERENCES}

KUPČÁK, V., 2003: Uplatnèní principư logistiky při použití harvestorových technologií. In: Zborník z medzinárodnej vedeckej konferencie „Logisticko-distribučné systémy", TU Zvolen, 2003, pp. 115-120, ISBN 80-228-1240-4.

LUKÁČ,T.,2005:Víceoperačnéstrojevlesnomhospodárstve. Vol. 1, Zvolen, 2005, 137 p., ISBN 80-228-1348-6.
SIMANOV, V., 1998: Harvestorovétechnologie: Podmínky jejich provozního využivání a perspektivy dalšího rozvoje v České republice. Vol. 1, Brno, 1998, 109 p., For EP Kapitál Group, a. s.

ŠAJÂNEK, V., 2007: Teoría a prax integrovaných t'ažbovo-dopravných technologii výroby dreva v lesníctve, Zvolen, 2007, 138 p., TU LF, Dissertation.

ULRICH, R., 2007: Uplatnění sortimentnich technologií. Vol. 1, Brno: issued in cooperation with VLS ČR, s. p., 2007, 64 p.

\section{Address}

Ing. Luboš Bartoš, Střední lesnická škola, Jurikova 588, 75301 Hranice, Česká republika, e-mail: bartos@slshranice.cz, Ing. Pavel Máchal, CSc., Institut celoživotního vzdělávání, Mendelova zemědělská a lesnická univerzita v Brně, Zemědělská 1, 61300 Brno, Česká republika, e-mail: pmachal@mendelu.cz, doc. Ing. Alois Skoupý, CSc., Ústav lesnické a dřevařské techniky, Mendelova zemědělská a lesnická univerzita v Brně, Zemědělská 3,613 00 Brno, Česká republika, e-mail: alois.skoupy@mendelu.cz 
